\title{
Molecular profiling of cervical cancer progression
}

\author{
T Hagemann', T Bozanovic', S Hooper', A Ljubic², VIF Slettenaar', JL Wilson', N Singh ${ }^{3}$, SA Gayther ${ }^{4}$, \\ JH Shepherd ${ }^{5}$ and POA Van Trappen $*, 1,5$
}

'Centre for Translational Oncology, Institute of Cancer and the CR-UK Clinical Centre, Barts and The London, Queen Mary's School of Medicine and Dentistry, London, UK; ${ }^{2}$ Department of Obstetrics and Gynaecology, Clinical Centre of Belgrade, Belgrade, Serbia-Montenegro, UK; ${ }^{3}$ Department of Histopathology, St Bartholomew's Hospital, London, UK; ${ }^{4}$ Translational Research Laboratories, Department of Gynaecological Oncology, University College London, London, UK; ${ }^{5}$ Gynaecological Cancer Centre, St. Bartholomew's Hospital, London, UK

Most cancer patients die of metastatic or recurrent disease, hence the importance to identify target genes upregulated in these lesions. Although a variety of gene signatures associated with metastasis or poor prognosis have been identified in various cancer types, it remains a critical problem to identify key genes as candidate therapeutic targets in metastatic or recurrent cancer. The aim of our study was to identify genes consistently upregulated in both lymph node micrometastases and recurrent tumours compared to matched primary tumours in human cervical cancer. Taqman Low-Density Arrays were used to analyse matched tumour samples, obtained after laser-capture microdissection of tumour cell islands for the expression of 96 genes known to be involved in tumour progression. Immunohistochemistry was performed for a panel of up- and downregulated genes. In lymph node micrometastases, most genes were downregulated or showed expressions equal to the levels found in primary tumours. In more than $50 \%$ of lymph node micrometastases studied, eight genes (AKT, BCL2, CSFRI, EGFRI, FGFI, MMP3, MMP9 and TGF- $\beta$ ) were upregulated at least two-fold. Some of these genes (AKT and MMP3) are key regulators of epithelial-mesenchymal transition in cancer. In recurrent tumours, almost all genes were upregulated when compared to the expression profiles of the matched primary tumours, possibly reflecting their aggressive biological behaviour. The two genes showing a consistent downregulated expression in almost all lymph node metastases and recurrent tumours were BAX and APC. As treatment strategies are very limited for metastatic and recurrent cervical cancer, the upregulated genes identified in this study are potential targets for new molecular treatment strategies in metastatic or recurrent cervical cancer.

British Journal of Cancer (2007) 96, 32 I -328. doi:I0.1038/sj.bjc.6603543 www.bjcancer.com

(c) 2007 Cancer Research UK

Keywords: molecular profiling; cervical cancer; lymph node; micrometastases; recurrent tumours

Cervical cancer is one of the leading causes of death in women worldwide, especially in developing countries owing to the lack of adequate screening programmes. The causative agent of cervical carcinogenesis is human papillomavirus (HPV), with insertion of viral oncogenes into the host DNA (Walboomers et al, 1999). More than 100 different HPV types have been identified and those associated with cervical cancer are subdivided as high-risk types, such as HPV16 and HPV18 (zur Hausen, 2000, 2002). However, the molecular mechanisms controlling cervical cancer progression are poorly understood.

Meta-analysis of DNA microarray data in cancer has revealed that hundreds of genes are differentially expressed between cancer tissues, including cervical cancer and their normal counterparts (Shim et al, 1998; Rubin et al, 2004; Segal et al, 2004; Hudelist et al, 2005). It became evident that many of these genes are epiphenomena and that only a subset of genes is associated with tumour

\footnotetext{
*Correspondence: Professor POA Van Trappen, Department of Gynaecology/Oncology, Academic Hospital Maastricht (azM), P. Debyelaan 25, PO Box 5800, 6202 AZ Maastricht, The Netherlands; E-mail: pvta@sgyn.azm.nl

Received 13 July 2006; revised 21 November 2006; accepted 22 November 2006
}

progression and metastasis (Ramaswamy et al, 2003; Roepman et al, 2005). In cervical cancer, gene expression profiling could be a useful tool for molecular classification and prediction of treatment response, but large studies are lacking (Wong et al, 2003). A 17gene signature has been associated with metastasis in a variety of human solid tumours, including lung, breast, prostate, colorectal, uterine and ovarian cancer (Ramaswamy et al, 2003). However, none of these genes represented markers of metastasis, and the signature reflected the gene expression profile of both neoplastic and stromal cells. To identify key genes involved in a particular cancer progression model it is essential to analyse matched tumour samples of different stages. These studies could direct new therapeutic strategies targeting specific candidate genes. Although a variety of genes have been implicated in cervical cancer invasion, migration and lymph node metastasis, most studies have used only cervical cancer cell lines or primary tumours (Shim et al, 1998; Ruutu et al, 2002; Van Trappen et al, 2002; Vazquez-Ortiz et al, 2005a). To our knowledge, no data are available on gene expression profile differences between primary tumours and matched metastatic or recurrent tumours in cervical cancer.

In this report, we attempt to identify genes up- or downregulated in lymph node micrometastases and recurrent tumours when compared with the matched primary tumours. To explore the gene expression profile of cervical cancer cells we used 
laser-capture microdissection to extract tumour cell islands. Taqman Low-Density Array, based on quantitative real-time RT-PCR, was used to screen matched tumour samples for 96 selected genes involved in several molecular processes such as angiogenesis, matrix degradation, cell cycle, oncogenic pathways, DNA repair mechanisms, adhesion, invasion, migration, cell proliferation and apoptosis. Immunohistochemistry was performed for several up- and downregulated genes.

\section{MATERIALS AND METHODS}

\section{Tissue specimens}

Tumour specimens were obtained from cervical cancer patients who underwent a radical hysterectomy and bilateral pelvic lymph node (LN) dissection for early-stage cervical cancer International Federation of Gynecology and Obstetrics (FIGO)-stage I- II at the Gynecological Cancer Centre of St Bartholomew's Hospital and the Department of Obstetrics and Gynecology of the Clinical Centre of Serbia between January 1999 and December 2002. From those patients, surgical specimens were formalin fixed immediately after removal and archival paraffin-embedded tissue was retrieved of following tissues, primary tumours, paired lymph nodes with micrometastasis or recurrent tumours where available. Patients were staged according to the guidelines of the FIGO. All specimens were reviewed by a pathologist (NS) of the Histopathology Department at St Bartholomew's Hospital and standard clinicopathological features (grade, histological subtype and lymph node metastasis) were recorded. All primary tumour samples included in the study were squamous cell carcinomas (SCC) with paired lymph node micrometastases (between 200 and $2000 \mu \mathrm{m}$ according to TNM classification) or recurrent tumours. The study was approved by the East London and the City Local Research Ethics Committee (T/02/046).

\section{Microdissection, RNA extraction and RT - PCR}

Before microdissection P.A.L.M slides ( $1 \mathrm{~mm}$ pen slides, P.A.L.M. Microlaser Technologies AG, Bernried, Germany) were first treated with $1 \times$ RNAse Zap treatment for $2 \mathrm{~min}$ and then washed three times in DEPC water. After drying, the slides were sterilised in UV light for $30 \mathrm{~min}$ in a UV stratalinker (Stratagene, La Jolla, CA, USA), membrane face up. Serial $7-\mu \mathrm{m}$ paraffin sections were cut with a fresh blade, mounted on prepared slides and incubated at RT for $30 \mathrm{~min}$ to achieve optimal tissue adhesion to the membrane. All staining baths were washed with RNAse Zap before use. Deparaffinisation was carried out by incubation in xylene $(2 \times 2 \mathrm{~min})$, followed by washing and rehydration in ethanol $(100 \%$ ethanol $30 \mathrm{~s}, 95 \%$ ethanol $30 \mathrm{~s}, 70 \%$ ethanol $30 \mathrm{~s}$ and $\mathrm{H}_{2} \mathrm{O} 10 \mathrm{~s}$ rinse). Sections were stained with haematoxylin for $1 \mathrm{~min}$ and washed twice for $1 \mathrm{~min}$ in $\mathrm{H}_{2} \mathrm{O}$. Dehydration followed, in ethanol (70\% ethanol $30 \mathrm{~s}, 95 \%$ ethanol $2 \times 30 \mathrm{~s}, 100 \%$ ethanol $1 \mathrm{~min}$ ). Slides were then ready after drying for processing by laser-assisted microdissection (LAMD).

For haematoxilyin and eosin staining, sections were processed as mentioned above. After dehydration in $70 \%$ ethanol for $30 \mathrm{~s}$, slides were stained for $5 \mathrm{~s}$ in eosin, then rinsed shortly in water. The dehydration was completed as mentioned above.

Microdissection of the membrane-mounted sections (P.A.L.M.) was performed with a high-resolution nitrogen UV laser (P.A.L.M. MicroLaser System, Zeiss, Oberkochen, Germany). In brief, RNA was extracted from laser microdissected tissue samples using the Ambion paraffin block RNA isolation kit (Ambion, Austin, TX, USA) according to the manufacturer's instructions. After the cutting event, the same laser was used to catapult the dissected material into a microtube cap containing $100 \mu \mathrm{l}$ Proteinase $\mathrm{K}$ digestion buffer ( $5 \mu \mathrm{l}$ proteinase $\mathrm{K})$, incubated for $1 \mathrm{~h}$ at $45^{\circ} \mathrm{C}$ and inactivated at $95^{\circ} \mathrm{C}$ for $10 \mathrm{~min}$. A $600 \mu \mathrm{l}$ volume of RNA extraction buffer was added and the sample was incubated for $5 \mathrm{~min}$ at RT. The sample was extracted using phenol: chloroform. The aqueous layer was transferred to a fresh tube and mixed with $2 \mu$ l linear acrylamide. Isopropanol $(1: 1)$ precipitation was carried out overnight. Following washing in $75 \%$ ethanol, the sample was resuspended in $17 \mu \mathrm{l} \mathrm{H}_{2} \mathrm{O}$. The RNA was DNase I $\left(2 \mathrm{U}^{-1}\right)$ treated for $15 \mathrm{~min}$ at $37^{\circ} \mathrm{C}$.

\section{Taqman Low-Density Arrays}

Taqman Low-Density Arrays (Part No. 4342261, Applied BioSystems, 850 Lincoln Centre Drive, Foster City, CA, USA) were used for gene expression profiling based on real-time quantitative RT-PCR to compare primary tumour and lymph node or recurrence tissue. Briefly, $2 \mu \mathrm{g}$ DNase-treated RNA from each sample was used for reverse transcription into $100 \mu \mathrm{l} \mathrm{cDNA}$. We used Random Hexamers (Promega, Madison, WI, USA) and MMLV RT enzyme (Roche Diagnostics, Mannheim, Germany) to synthesise cDNA. For each sample, $40 \mu \mathrm{l}$ of cDNA synthesised above were then mixed with $210 \mu$ l Taqman universal PCR master mix (PE Applied Biosystems, New Jersey, NJ, USA) and $170 \mu$ PCR water to form reaction mix. A $400 \mu \mathrm{l}$ portion of this reaction mix was then put on microfluidic card into 192 mini wells containing primers and probes of 96 genes in duplicate. These 96 genes, known to be involved in tumour progression, included DNA damage repair genes, cell cycle control genes, common oncogenes, tumour suppressor genes and metastasis-associated genes. Human $18 \mathrm{~S}$ and GAPDH were used as endogenous controls. For each 384 well card, two cDNA samples (matched) were included at the same time for real-time RT-PCR reaction and analysis. The real-time RT-PCR reaction and laser scanning was performed on ABI 7900 HT genotyper with SDS2.1 software. The expression level of each gene is analysed on the mean of its duplicates. Only the genes with reproducible amplification curves of both duplicates were analysed and presented.

\section{Immunohistochemistry}

Immunohistochemical staining was performed for candidate genes upregulated at mRNA level. Primary human monoclonal antibodies to EGF-R (clone 1F4, Cell Signaling Technology, Inc. 3 Trask Lane, Danvers, MA, USA), AKT, FGF1, BCL2, CSF1R, MMP3 and MMP9 (R\&D systems, Abingdon, UK), Her2/erbB2 (Cell Signaling Technology, USA), phospho-Her2/erbB2 (Tyr1221/1222, Cell Signaling Technology, USA) were used for staining. Briefly, slides were blocked with horse serum $(5 \mathrm{~min})$, incubated in a humid chamber for $60 \mathrm{~min}$ with primary antibody, and for $30 \mathrm{~min}$ each with biotinylated secondary antibody and avidin-biotinylated horseradish peroxidase complex (ABC). Endogenous peroxidase activity was blocked by $0.5 \%$ hydrogen peroxide $\left(\mathrm{H}_{2} \mathrm{O}_{2}\right)$ in methanol for $15 \mathrm{~min}$. Washing was carried out using PBS buffer. Colour development was obtained with 3,3-diaminobenzidinetetrahydrochloride for $10 \mathrm{~min}$. Sections were counterstained in toluidine blue for $4 \mathrm{~min}$, washed for $4 \mathrm{~min}$ in water, and dried in ethanol. Sections were evaluated by quantitative analysis, the number of immunohistochemical (IHC)-positive tumour cells were calculated on the total number of tumour cells (percentage) in three high-power fields per section. The median was calculated for both primary tumours and metastases/recurrent tumours and statistical differences were analysed using the Fisher's Exact test.

\section{RESULTS}

We analysed 25 paired tumour samples for gene expression profile differences: 11 primary cervical tumours with matched lymph node micrometastases and 14 primary cervical tumours with 
matched recurrent tumours. Laser-assisted microdissection was used to extract tumour cell islands from those samples. The appearance of tissue before and after microdissection is illustrated in Figure 1. RNA was extracted and subsequent cDNA was analysed using Taqman Low-Density Arrays. A summary of the genes whose expression was altered consistently in replicate experiments is presented in Figure 2. The figure shows genes upregulated (red) or downregulated (green) (at least 2-fold) in the lymph node micrometastases $(n=11)$ and recurrent tumours ( $n=14)$ respectively, when compared with the expression profiles found in primary cervical tumours. Genes that did not vary in their expression level are shown in white and genes with unsatisfactory results (i.e. aberrant amplification curves or no expression) were labelled black. The housekeeping gene GAPDH showed identical expression levels in all matched samples analysed apart from one.

In lymph node micrometastases, most genes were downregulated or showed equal expression when compared with the expression levels in primary cervical tumours. In more than half $(>6 / 11)$ of these, there were eight genes consistently $>2$-fold upregulated in lymph node micrometastases when compared with primary tumours. These eight genes were AKT, BCL2, CSFR1, EGFR1, FGF1, MMP3, MMP9 and transforming growth factor (TGF)- $\beta$. Twenty-five genes were consistently $<2$-fold downregulated (Table 1$)$.

In recurrent tumours, almost all genes were upregulated ( $>2$-fold), possibly reflecting their aggressive biological behaviour. In total, 88 of 96 genes were upregulated (including the eight genes commonly upregulated in lymph node micrometastases) in more than $50 \%(>7 / 14)$ of recurrent cases. The two genes showing a consistent pattern of downregulated expression in both lymph node micrometastases and recurrent tumours were BAX and APC.

\section{Immunohistochemical staining}

Immunohistochemical (IHC) staining was performed for both up- and downregulated gene(s) in all LN micrometastases $(n=11)$ and compared to the staining results in the primary tumours. Quantitative analysis was performed by calculating the number of IHC-positive tumour cells on the total number of tumour cells (percentage) in three high power fields per section. The median was calculated for both primary tumours and lymph node micrometastases and statistical differences were analysed using the Fisher's Exact test.

AKT was significantly upregulated in lymph node micrometasases when compared with the primary tumour $(P=0.0064$; Figure 3). Similarly, immunohistochemistry also confirmed upregulation of CSF1R and EGFR in lymph node micrometastases (data not shown). We could also confirm significant downregulation of ERBB2 $(P=0.0006$; Figure 3$)$. Immunohistochemical differences for MMP3, MMP9, FGF1 and BCL2 were inconclusive (data not shown). The reason therefore could either be the tissue embedding technique or that there is still a post-transcriptional modification of these genes.
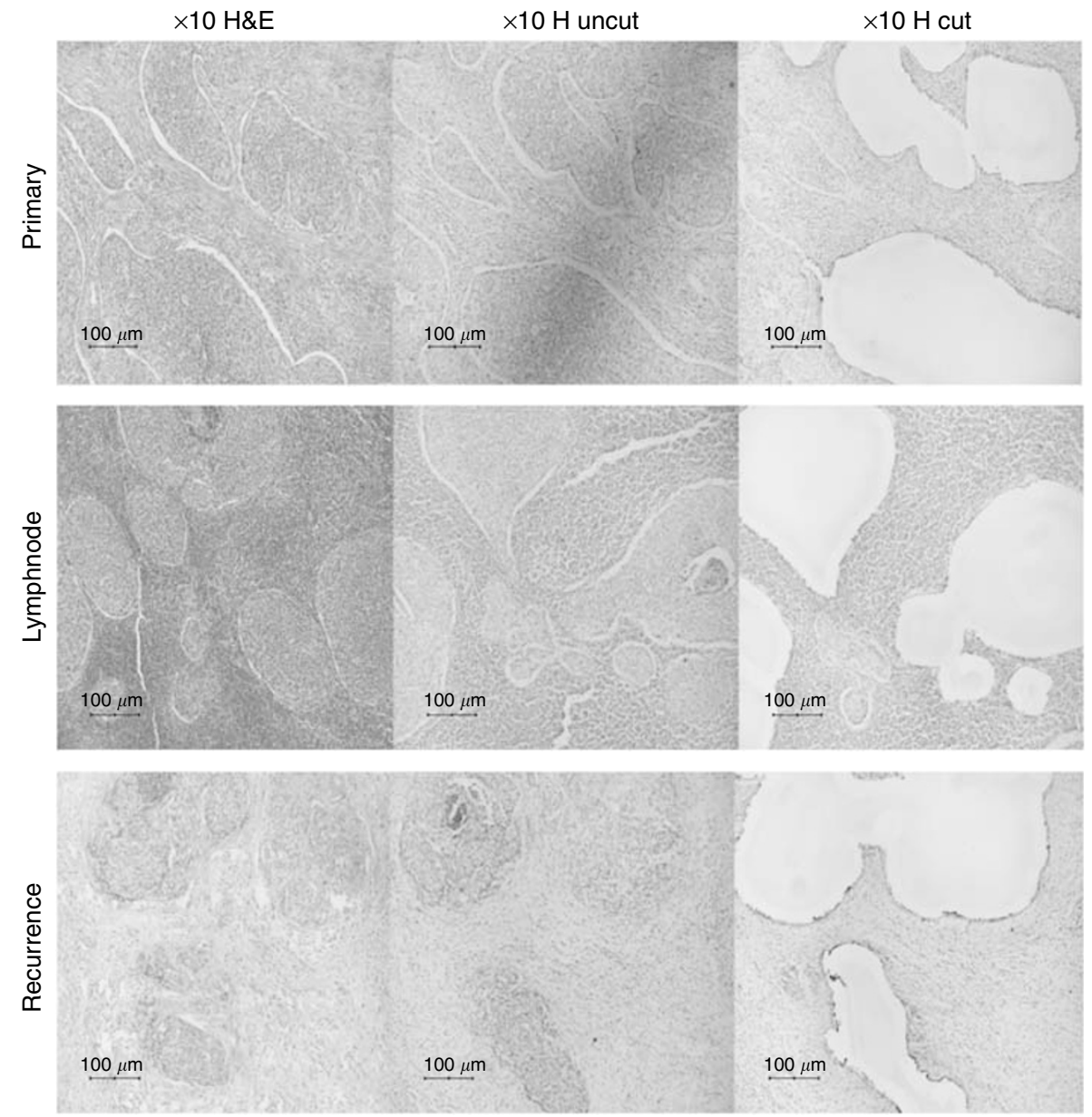

Figure I Slides of primary cervical cancers, lymph node micrometastases and recurrent tumours for haematoxylin and eosin (H\&E) staining (first column; $4 \mu \mathrm{m}$ section) and haematoxylin $(\mathrm{H})$ staining before (second column; $7 \mu \mathrm{m}$ section) and after microdissection (third column; $7 \mu \mathrm{m}$ section). 


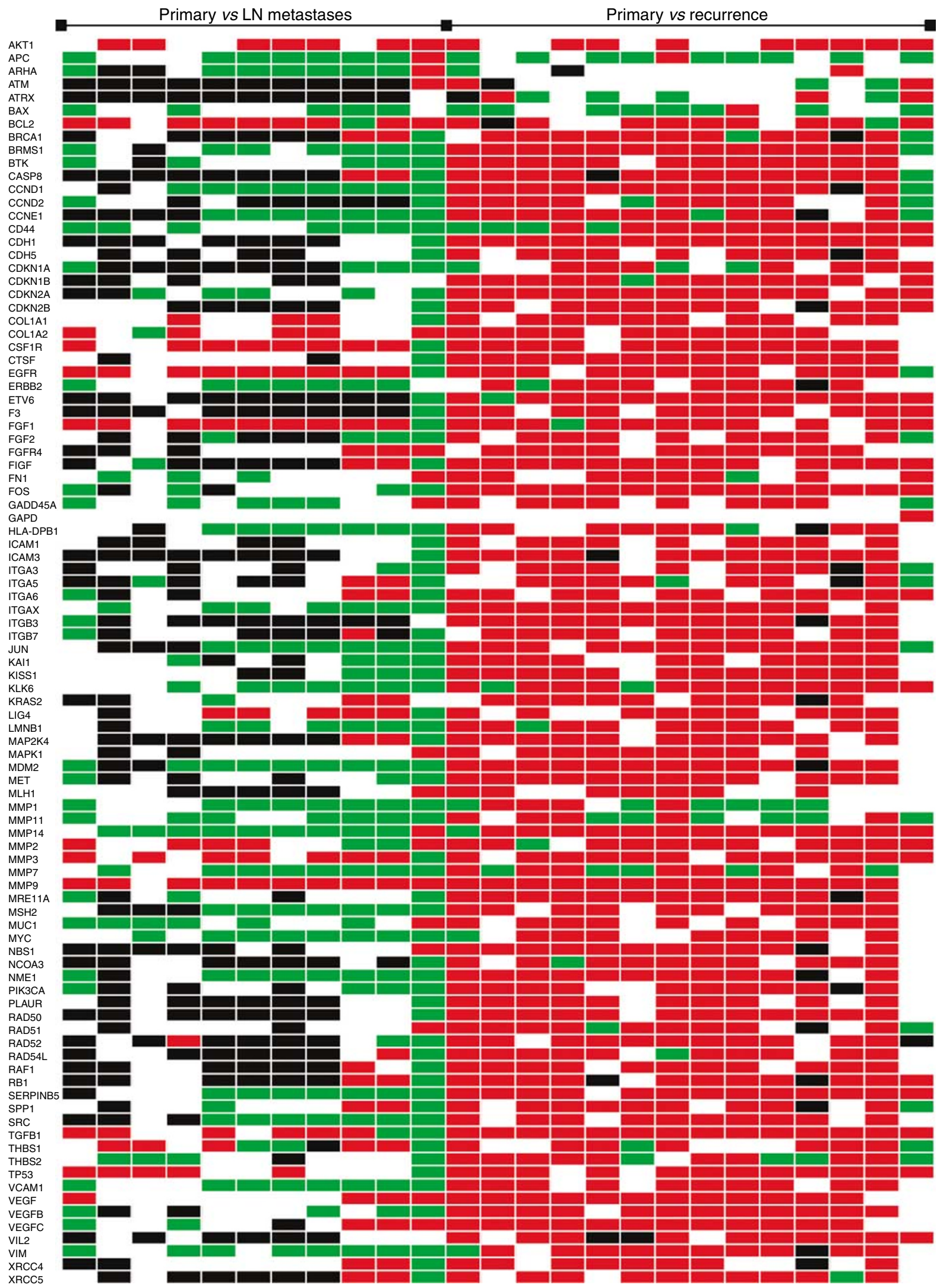

Figure 2 Genes differentially expressed between LN micrometastases or recurrent tumours and matched primary cervical cancers. The figure shows genes upregulated (red) or downregulated (green) (at least two-fold) in LNM $(n=1 \mathrm{I})$ and RT $(n=\mid 4)$ respectively, when compared with the expression profiles found in primary tumours. Genes that did not vary in their expression level are shown in white, and genes with unsatisfactory results (i.e. aberrant amplification curves or no expression) were labelled black. 
Table I Genes differentially expressed in lymph node micrometastases when compared with matched primary cervical cancers

\begin{tabular}{|c|c|c|}
\hline Gene & Gene name & ID \\
\hline AKT & v-akt murine thymoma viral oncogenes homologue I & Hs00l78289_ml \\
\hline EGFRI & Epidermal growth factor receptor & $\mathrm{Hs} 00193306$ m I \\
\hline FGFI & Fibroblast growth factor I (acidic) & Hs00265254_ml \\
\hline MMP3 & Matrix metalloproteinase 3 (stromelysin I, progelatinase) & Hs00233962_ml \\
\hline \multicolumn{3}{|c|}{ Downregulated in LN metastases } \\
\hline$A P C^{\circ}$ & Adenomatosis polyposis coli & Hs00I8I05I_ml \\
\hline ARHA & Ras homologue gene family, member A & Hs00357608_ml \\
\hline BRMSI & Breast cancer metastasissuppressor I (Interim) & Hs00363036_ml \\
\hline CCNDI & Cyclin DI (PRADI: parathyroid adenomatosis I) & $\mathrm{Hs} 0021$ I039_m I \\
\hline CCNEI & Cyclin EI & Hs00233356_ml \\
\hline KLK6 & Kallikrein 6 (neurosin, zyme) & $\mathrm{Hs} 00 \mathrm{I} 60519-\mathrm{ml}$ \\
\hline LMNBI & Lamin BI & Hs00194369_ml \\
\hline MDM2 & Mdm2, transformed $3 T 3$ cell double minute 2, p53-binding protein & $\mathrm{Hs} 002428 \mathrm{I}$ _m I \\
\hline MMPI & Matrix metalloproteinase I (interstitial collagenase) & Hs00233958_ml \\
\hline MMP7 & Matrix metalloproteinase 7 (matrilysin, uterine) & Hs00I59I63_ml \\
\hline MMPII & Matrix metalloproteinase II (stromelysin 3) & $\mathrm{Hs} 0017 \mid 829 \_\mathrm{ml}$ \\
\hline MMPI4 & Matrix metalloproteinase 14 (membrane-inserted) & Hs00237II9_ml \\
\hline $\mathrm{MSH} 2$ & mutS homologue 2, colon cancer, nonpolyposis type I (Escherichia. coli) & Hs00I79887_ml \\
\hline $\mathrm{MUCl}$ & Mucin I, transmembrane & Hs004l0317_ml \\
\hline MYC & v-myc myelocytomatosis viral oncogenes homologue (avian) & Hs00I53408_ml \\
\hline NMEI & Nonmetastatic cells 1, protein (NM23A) expressed in & Hs00264824_ml \\
\hline SERPINB5 & Serine (or cysteine) proteinase inhibitor, clade B (ovalbumin), member5 & Hs00I84728_ml \\
\hline SRC & v-src sarcoma (Schmidt-Ruppin A-2) viral oncogene homologue (avian) & $\mathrm{Hs} 00 \mathrm{I} 78494 \_\mathrm{ml}$ \\
\hline VCAMI & Vascular cell adhesion molecule I & Hs00I74239_ml \\
\hline
\end{tabular}
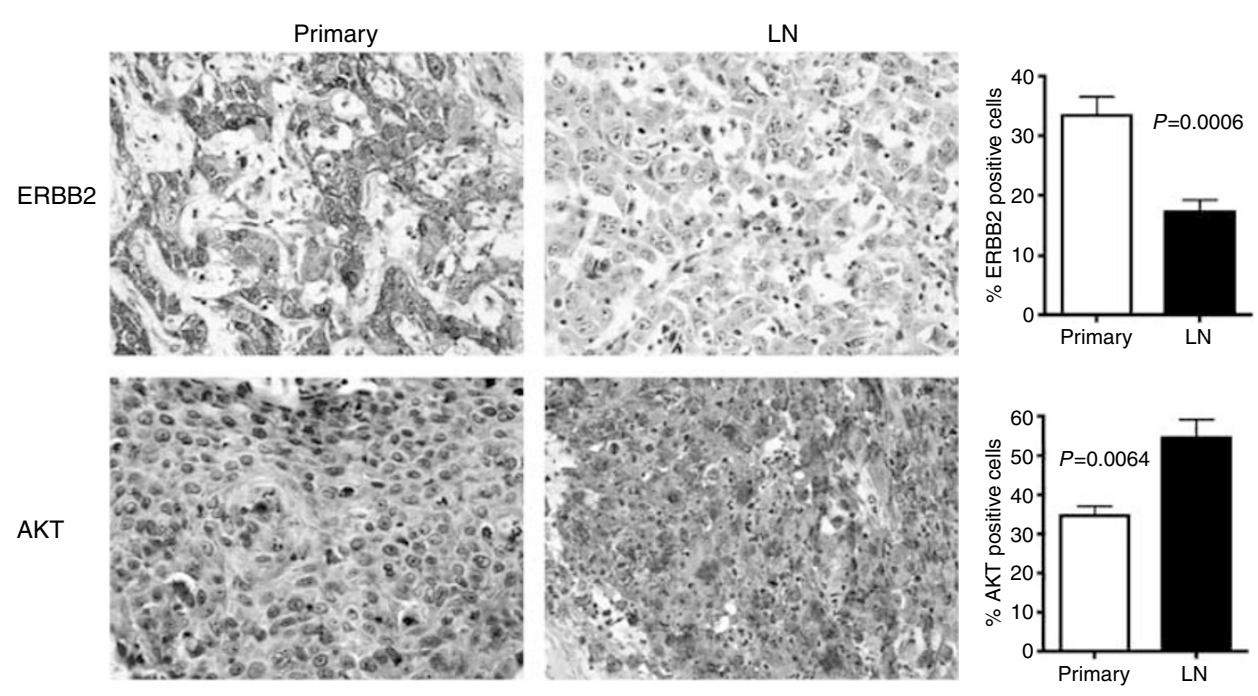

Figure 3 Immunohistochemistry (IHC) for ERBB2 and AKT in matched primary cervical tumours and LN micrometastases. Quantitative analysis of IHCpositive cells revealed that ERBB2 showed a significant stronger expression in the primary tumour $(P=0.0006)$, whereas AKT showed a significant stronger expression in the $L N$ metastases $(P=0.0064)$.

\section{DISCUSSION}

In this study, we have investigated differential gene expression profiles between LN micrometastases or recurrent tumours and matched primary cervical cancers. We used a unique set of cervical cancer samples from patients who underwent a radical hysterectomy and pelvic lymph node dissection for presumed early-stage cervical cancer. However, these patients demonstrated on histological examination 
small clusters of LN metastases (micrometastases), which were not identifiable on preoperative investigations (imaging) or during surgery. Cervical cancers with LN metastases are normally treated by primary chemo-radiotherapy, hence the unique set of matched primary tumours and LN micrometastases obtained for this study.

In order to obtain expression profiles of tumour cell islands only we used LAMD of paraffin-embedded tissue and microfluidic cards based on real-time quantitative RT - PCR, a technique similar to that described previously (Specht et al, 2001). This method was used, as LN micrometastases can only be identified after histological examination of paraffin-embedded tissue, and fresh frozen human samples of LN micrometastases are difficult, if not impossible to obtain. The microfluidic card contained 96 genes previously described in tumour progression or identified as markers of metastasis or clinical outcome (van 't Veer et al, 2002; Ramaswamy et al, 2003; Rhodes and Chinnaiyan, 2004; Segal et al, 2004; Roepman et al, 2005). Data obtained from microarrays of RNA retrieved from paraffin-embedded tissue are not reliable hence our application of microfluidic cards with selected genes. Although microarrays could give a broader signature we aimed at identifying a selective gene signature both in LN micrometastases and recurrent tumours to identify markers as potential therapeutic targets. The 96 selected genes are involved in several molecular processes such as angiogenesis, matrix degradation, cell cycle, oncogenic pathways, DNA repair mechanisms, adhesion, invasion, migration, cell proliferation and apoptosis. In LN metastases, most genes were downregulated or showed equal expression with the levels found in primary tumours, possibly reflecting their motility behaviour requiring (temporarily) less molecular pathways compared with primary tumours. In more than $50 \%$ of LN metastases, eight genes were upregulated at least two-fold and 25 genes were downregulated at least two-fold. In recurrent tumours, almost all genes were upregulated at least two-fold, possibly reflecting their aggressive biological behaviour. The two genes showing a consistent pattern of downregulated expression in both LN metastases and recurrent tumours were BAX and APC. The functional role of both genes has been well described in cancer, with the BCL2 homologue gene BAX playing a key role in tumour apoptosis as a proapoptotic gene and APC acting as a tumour suppressor gene, which is frequently inactivated in cervical cancer by hypermethylation (LeBlanc et al, 2002; Reesink-Peters et al, 2004; Soufla et al, 2005).

Here we describe eight genes (AKT, BCL2, CSFR1, EGFR1, FGF1, MMP3, MMP9 and TGF- $\beta$ ) found to be commonly upregulated in LN micrometastases in cervical cancer, as well as their functional role previously described in cancer cell lines. These genes were also upregulated in almost all recurrent tumours analysed making them interesting targets for therapeutic strategies. AKT is a serine/ threonine kinase acting as a signal transduction protein and downstream mediator of phosphatidylinositol-3-kinase (PI3K) that plays a central role in tumour progression and influences prognosis in several cancers (Lim et al, 2005; Tang et al, 2006). The oncogenic pathway PI3K/AKT plays a central role in epithelial-mesenchymal transition, a critical feature in cancer invasion and metastasis by reducing intercellular adhesion and increasing cancer cell motility (Larue and Bellacosa, 2005). Upregulation of AKT in LN metastases in this study suggests its potential role in epithelial-mesenchymal transition of cervical cancer cells during metastasis. In the cervical cancer cell line C33A, the PI3K/AKT pathway has a key role in cancer progression towards a metastatic phenotype (Mora et al, 2006). BCL2 is an antiapoptotic gene and increased expression is associated with poor responses to systemic treatment of cancer (Andersen et al, 2005; Kausch et al, 2005). Colony stimulating factor-1 receptor (CSFR1) is involved in tumour cell invasion and migration, and high level expression is associated with poor prognosis in cancer patients (Tsuzuki et al, 2005). In various cervical cancer cell lines known to exhibit different degrees of aggressivity, the highest levels of colony stimulating factor are found in the most aggressive cell lines (Bretscher et al, 2000). The CSF1 produced by cancer cells promotes the expression of EGF by macrophages (Goswami et al, 2005). In addition, EGF promotes the expression of CSF-1 by cancer cells, thereby generating a positive feedback loop. Disruption of this loop by blockade of either EGF receptor or CSF-1 receptor signalling is sufficient to inhibit both macrophage and tumour cell migration and invasion. Epidermal growth factor receptor (EGFR) is highly expressed in many tumours, including those of the cervix, and there is a clear relationship between HPV E6/E7 oncoproteins and EGFR function ( $\mathrm{Hu}$ et al, 1997). Blockade of EGFR in cervical cancer cell lines induces increased expression of genes that stimulate apoptosis and suppresses experimental metastasis (Kim et al, 2004; Woodworth et al, 2005). Fibroblast growth factor 1 (FGF1) is a growth factor for both tumour and stromal (endothelial) cells and induces the expression of matrix metalloproteinases (MMPs) and angiogenesis in cancer, hence its involvement in tumour progression (Aonuma et al, 1998; Kwabi-Addo et al, 2004; Udayakumar et al, 2004). The MMPs, a family of proteolytic enzymes that degrade different components of the extracellular matrix, play important roles in the different stages of tumour progression. Matrix metalloproteinase 3 (stromelysin 1) plays an important role in breast cancer progression, and it has shown to have increased levels, as well as activity, in breast cancer brain metastasis in a rat model (Mendes et al, 2005). Similar to AKT, MMP3 can also cause epithelial-mesenchymal transition in cancer (Radisky et al, 2005). Matrix metalloproteinase 9 plays a central role in connective tissue degradation, tumourinduced angiogenesis, cell proliferation/apoptosis and cell migration in various tumour types including cervical cancer (van Kempen and Coussens, 2002; Van Trappen et al, 2002; Zucker and Vacirca, 2004; Vazquez-Ortiz et al, 2005b). Recently, one study has shown that MMP9 forms a complex with the hyaluronan receptor CD44 on the surface of breast cancer cells and activates downstream TGF- $\beta$, facilitating tumour cell survival, invasion and metastasis ( $\mathrm{Yu}$ and Stamenkovic, 2004). Similar mechanism(s) could occur at the level of tumour cell survival of LN micrometastases in cervical cancer. Transforming growth factor (TGF)- $\beta$ stimulates epithelialmesenchymal transition of SiHa cervical cancer cells, indicating a positive role in the invasive transition of cervical cancer (Yi et al, 2002). Although TGF- $\beta$ is both a tumour suppressor and tumour promoter, TGF- $\beta$ inhibitors are currently widely tested for the treatment of cancer (Muraoka-Cook et al, 2004; Elliott and Blobe, 2005; Lahn et al, 2005). Various genes were downregulated in LN micrometastases, such as major histocompatibility complex (MHC) class II antigens and NME1. Underexpression of MHC molecules involved in T-lymphocyte-mediated tumour cell recognition may be one important escape mechanism used by metastatic cancer cells, and these cells can be ignored by the immune system for a long time despite the presence of immunocompetent cells (Pantel et al, 1991). NME1, a metastasis-suppressor gene, shows reduced expression in highly metastatic breast cancer cells and was downregulated in cervical cancer LN metastases in this study (Rubio et al, 2006).

Although several cancer gene signatures have shown prognostic significance in a variety of cancers, it remains a critical problem to identify key genes as candidate therapeutic targets. As cancer cells require the expression of different genes along the different stages of tumour progression, it is essential to obtain expression profile data from the different steps of tumour progression. In this study, we have identified a panel of tumour-associated genes upregulated in LN micrometastases, as well as in recurrent tumours which could be potential therapeutic targets in metastatic or recurrent cervical cancer.

\section{ACKNOWLEDGEMENTS}

PVT was supported by a Clinician Scientist Grant from Cancer Research UK. We also thank Stephen Robinson for his assistance in the figures. 


\section{REFERENCES}

Andersen MH, Becker JC, Straten P (2005) Regulators of apoptosis: suitable targets for immune therapy of cancer. Nat Rev Drug Discov 4: 399-409

Aonuma M, Iwahana M, Nakayama Y, Hirotani K, Hattori C, Murakami K, Shibuya M, Tanaka NG (1998) Tumorigenicity depends on angiogenic potential of tumor cells: dominant role of vascular endothelial growth factor and/or fibroblast growth factors produced by tumor cells. Angiogenesis 2: 57-66

Bretscher V, Andreutti D, Neuville P, Martin M, Martin F, Lefebvre O, Gilles C, Benzonana G, Gabbiani G (2000) GM-CSF expression by tumor cells correlates with aggressivity and with stroma reaction formation. J Submicrosc Cytol Pathol 32: 525-533

Elliott RL, Blobe GC (2005) Role of transforming growth factor Beta in human cancer. J Clin Oncol 23: 2078-2093

Goswami S, Sahai E, Wyckoff JB, Cammer M, Cox D, Pixley FJ, Stanley ER, Segall JE, Condeelis JS (2005) Macrophages promote the invasion of breast carcinoma cells via a colony-stimulating factor-1/epidermal growth factor paracrine loop. Cancer Res 65: 5278-5283

Hu G, Liu W, Mendelsohn J, Ellis LM, Radinsky R, Andreeff M, Deisseroth AB (1997) Expression of epidermal growth factor receptor and human papillomavirus E6/E7 proteins in cervical carcinoma cells. J Natl Cancer Inst 89: $1271-1276$

Hudelist G, Czerwenka K, Singer C, Pischinger K, Kubista E, Manavi M (2005) cDNA array analysis of cytobrush-collected normal and malignant cervical epithelial cells: a feasibility study. Cancer Genet Cytogenet 158: $35-42$

Kausch I, Jiang H, Thode B, Doehn C, Kruger S, Jocham D (2005) Inhibition of bcl-2 enhances the efficacy of chemotherapy in renal cell carcinoma. Eur Urol 47: $703-709$

Kim GE, Kim YB, Cho NH, Chung HC, Pyo HR, Lee JD, Park TK, Koom WS, Chun M, Suh CO (2004) Synchronous coexpression of epidermal growth factor receptor and cyclooxygenase- 2 in carcinomas of the uterine cervix: a potential predictor of poor survival. Clin Cancer Res 10: 1366-1374

Kwabi-Addo B, Ozen M, Ittmann M (2004) The role of fibroblast growth factors and their receptors in prostate cancer. Endocr Relat Cancer 11: $709-724$

Lahn M, Kloeker S, Berry BS (2005) TGF-beta inhibitors for the treatment of cancer. Expert Opin Investig Drugs 14: 629-643

Larue L, Bellacosa A (2005) Epithelial-mesenchymal transition in development and cancer: role of phosphatidylinositol $3^{\prime}$ kinase/AKT pathways. Oncogene 24: $7443-7454$

LeBlanc H, Lawrence D, Varfolomeev E, Totpal K, Morlan J, Schow P, Fong S, Schwall R, Sinicropi D, Ashkenazi A (2002) Tumor-cell resistance to death receptor-induced apoptosis through mutational inactivation of the proapoptotic Bcl-2 homolog Bax. Nat Med 8: 274-281

Lim J, Kim JH, Paeng JY, Kim MJ, Hong SD, Lee JI, Hong SP (2005) Prognostic value of activated Akt expression in oral squamous cell carcinoma. J Clin Pathol 58: 1199-1205

Mendes O, Kim HT, Stoica G (2005) Expression of MMP2, MMP9 and MMP3 in breast cancer brain metastasis in a rat model. Clin Exp Metastasis 22: $237-246$

Mora N, Rosales R, Rosales C (2006) R-Ras promotes metastasis of cervical cancer epithelial cells. Cancer Immunol Immunother July 22 (Epub ahead of print)

Muraoka-Cook RS, Kurokawa H, Koh Y, Forbes JT, Roebuck LR, BarcellosHoff MH, Moody SE, Chodosh LA, Arteaga CL (2004) Conditional overexpression of active transforming growth factor betal in vivo accelerates metastases of transgenic mammary tumors. Cancer Res 64: 9002-9011

Pantel K, Schlimok G, Kutter D, Schaller G, Genz T, Wiebecke B, Backmann R, Funke I, Riethmuller G (1991) Frequent downregulation of major histocompatibility class I antigen expression on individual micrometastatic carcinoma cells. Cancer Res 51: $4712-4715$

Radisky DC, Levy DD, Littlepage LE, Liu H, Nelson CM, Fata JE, Leake D, Godden EL, Albertson DG, Nieto MA, Werb Z, Bissell MJ (2005) Rac1b and reactive oxygen species mediate MMP-3-induced EMT and genomic instability. Nature 436: $123-127$

Ramaswamy S, Ross KN, Lander ES, Golub TR (2003) A molecular signature of metastasis in primary solid tumors. Nat Genet 33: 49-54

Reesink-Peters N, Wisman GB, Jeronimo C, Tokumaru CY, Cohen Y, Dong SM, Klip HG, Buikema HJ, Suurmeijer AJ, Hollema H, Boezen HM, Sidransky D, van der Zee AG (2004) Detecting cervical cancer by quantitative promoter hypermethylation assay on cervical scrapings: a feasibility study. Mol Cancer Res 2: 289-295
Rhodes DR, Chinnaiyan AM (2004) Bioinformatics strategies for translating genome-wide expression analysis into clinically useful cancer markers. Ann NY Acad Sci 1020: $32-40$

Roepman P, Wessels LF, Kettelarij N, Kemmeren P, Miles AJ, Lijnzaad P, Tilanus MG, Koole R, Hordijk GJ, van der Vliet PC, Reinders MJ, Slootweg PJ, Holstege FC (2005) An expression profile for diagnosis of lymph node metastases from primary head and neck squamous cell carcinomas. Nat Genet 37: $182-186$

Rubin MA, Varambally S, Beroukhim R, Tomlins SA, Rhodes DR, Paris PL, Hofer MD, Storz-Schweizer M, Kuefer R, Fletcher JA, Hsi BL, Byrne JA, Pienta KJ, Collins C, Sellers WR, Chinnaiyan AM (2004) Overexpression, amplification, and androgen regulation of TPD52 in prostate cancer. Cancer Res 64: $3814-3822$

Rubio SA, Martinez SE, Corona JS, Ruiz AP, Rincon AE, Lagunas IA, Camacho JG, Moguel MC (2006) EcoRI polymorphism of the metastasissuppressor gene NME1 in Mexican patients with breast cancer. Breast Cancer Res Treat 96: 159-161

Ruutu M, Peitsaro P, Johansson B, Syrjanen S (2002) Transcriptional profiling of a human papillomavirus 33-positive squamous epithelial cell line which acquired a selective growth advantage after viral integration. Int J Cancer 100: $318-326$

Segal E, Friedman N, Koller D, Regev A (2004) A module map showing conditional activity of expression modules in cancer. Nat Genet 36: $1090-1098$

Shim C, Zhang W, Rhee CH, Lee JH (1998) Profiling of differentially expressed genes in human primary cervical cancer by complementary DNA expression array. Clin Cancer Res 4: 3045-3050

Soufla G, Baritaki S, Sifakis S, Zafiropoulos A, Spandidos DA (2005) Transcriptional inactivation of $\mathrm{p} 53, \mathrm{Bax}, \mathrm{Bcl}-2$ and $\mathrm{Mdm} 2$ correlates with malignant transformation of the uterine cervix. Int J Biol Markers 20: $18-27$

Specht K, Richter T, Muller U, Walch A, Werner M, Hofler H (2001) Quantitative gene expression analysis in microdissected archival formalin-fixed and paraffin-embedded tumor tissue. Am J Pathol 158: $419-429$

Tang JM, He QY, Guo RX, Chang XJ (2006) Phosphorylated Akt overexpression and loss of PTEN expression in non-small cell lung cancer confers poor prognosis. Lung Cancer 51: 181-191

Tsuzuki H, Sunaga H, Ito T, Narita N, Sugimoto C, Fujieda S (2005) Reliability of platelet-derived endothelial cell growth factor as a prognostic factor for oral and oropharyngeal carcinomas. Arch Otolaryngol Head Neck Surg 131: $1071-1078$

Udayakumar TS, Nagle RB, Bowden GT (2004) Fibroblast growth factor-1 transcriptionally induces membrane type-1 matrix metalloproteinase expression in prostate carcinoma cell line. Prostate 58: $66-75$

van ' $t$ Veer LJ, Dai H, van de Vijver MJ, He YD, Hart AA, Mao M, Peterse HL, van der Kooy K, Marton MJ, Witteveen AT, Schreiber GJ, Kerkhoven RM, Roberts C, Linsley PS, Bernards R, Friend SH (2002) Gene expression profiling predicts clinical outcome of breast cancer. Nature 415: $530-536$

Van Kempen LC, Coussens LM (2002) MMP9 potentiates pulmonary metastasis formation. Cancer Cell 2: 251-252

Van Trappen PO, Ryan A, Carroll M, Lecoeur C, Goff L, Gyselman VG, Young BD, Lowe DG, Pepper MS, Shepherd JH, Jacobs IJ (2002) A model for co-expression pattern analysis of genes implicated in angiogenesis and tumour cell invasion in cervical cancer. $\mathrm{Br} \mathrm{J}$ Cancer 87: $537-544$

Vazquez-Ortiz G, Ciudad CJ, Pina P, Vazquez K, Hidalgo A, Alatorre B, Garcia JA, Salamanca F, Peralta-Rodriguez R, Rangel A, Salcedo M (2005a) Gene identification by cDNA arrays in HPV-positive cervical cancer. Arch Med Res 36: 448-458

Vazquez-Ortiz G, Pina-Sanchez P, Vazquez K, Duenas A, Taja L, Mendoza P, Garcia JA, Salcedo M (2005b) Overexpression of cathepsin f, matrix metalloproteinases 11 and 12 in cervical cancer. BMC Cancer 5: 68

Walboomers JM, Jacobs MV, Manos MM, Bosch FX, Kummer JA, Shah KV, Snijders PJ, Peto J, Meijer CJ, Munoz N (1999) Human papillomavirus is a necessary cause of invasive cervical cancer worldwide. J Pathol 189: $12-19$

Wong YF, Selvanayagam ZE, Wei N, Porter J, Vittal R, Hu R, Lin Y, Liao J, Shih JW, Cheung TH, Lo KW, Yim SF, Yip SK, Ngong DT, Siu N, Chan LK, Chan CS, Kong T, Kutlina E, McKinnon RD, Denhardt DT, Chin KV, 
Chung TK (2003) Expression genomics of cervical cancer: molecular classification and prediction of radiotherapy response by DNA microarray. Clin Cancer Res 9: 5486-5492

Woodworth CD, Michael E, Marker D, Allen S, Smith L, Nees M (2005) Inhibition of the epidermal growth factor receptor increases expression of genes that stimulate inflammation, apoptosis, and cell attachment. Mol Cancer Ther 4: 650-658

Yi JY, Hur KC, Lee E, Jin YJ, Arteaga CL, Son YS (2002) TGFbeta1-mediated epithelial to mesenchymal transition is accompanied by invasion in the SiHa cell line. Eur J Cell Biol 81: 457-468
Yu Q, Stamenkovic I (2004) Transforming growth factor-beta facilitates breast carcinoma metastasis by promoting tumor cell survival. Clin Exp Metastasis 21: 235-242

Zucker S, Vacirca J (2004) Role of matrix metalloproteinases (MMPs) in colorectal cancer. Cancer Metastasis Rev 23: $101-117$

zur Hausen H (2000) Papillomaviruses causing cancer: evasion from host-cell control in early events in carcinogenesis. J Natl Cancer Inst 92: $690-698$

zur Hausen H (2002) Papillomaviruses and cancer: from basic studies to clinical application. Nat Rev Cancer 2: $342-350$ 